\title{
Penerapan Model Pembelajaran Project Based Learning Melalui Media Vlog Untuk Meningkatkan Minat Belajar Dan Prestasi Belajar Siswa
}

\author{
Nining Masrucha ${ }^{1}$, I Gusti Ayu Agung Sinta Diarini ${ }^{2}$, I Wayan Suryanto ${ }^{3}$ \\ 1,2,3 Universitas Dhyana Pura \\ 1niningmasrucha99@gmail.com, 2ºungsinta@undhirabali.ac.id, \\ suryanto@undhirabali.ac.id
}

\begin{tabular}{l}
\hline Keywords: \\
\hline Project Based \\
Learning; Vlog; \\
Interests; \\
Achievement \\
\hline
\end{tabular}

Kata Kunci:

Project Based Learning; Vlog; Minat Belajar Siswa; Prestasi Belajar

\begin{abstract}
Purpose of this study is: To find out whether the application of learning model project based learning through vlog media is able to increase student interest in learning, and student achievement and is able to jointly increase the interest in learning and achievement of class XI Catering 5 students in the subject of food and beverage servicee at SMK Negeri 2 Tabanan. This type of research is classroom action research (CAR) with quantitative descriptive data analysis techniques. The object of research is interest in learning and student achievement and the sample in this study was class XI Catering 5 SMK Negeri 2 Tabanan. The results showed that learning achievement has increased supported by an increase in student learning outcomes. This is supported by the successful application of themodel project based learning through vlog media which has an effect on increasing student interest in learning which is shown from feelings of pleasure, student involvement, interest, and attention of students. This also proves that the application of themodel project-based learning through vlog media has succeeded in increasing student interest in learning and learning achievement.
\end{abstract}


ini di dukung oleh keberhasilan penerapan model project based learning melalui media vlog yang berpengaruh pada peningkatan minat siswa untuk belajar yang di tunjukkan dari perasaan senang, keterlibatan siswa, ketertarikan, dan perhatian siswa. Hal ini sekaligus membuktikan bahwa penerapan model pembelajaran project based learning melalui media vlog telah berhasil meningkatkan minat belajar dan prestasi belajar siswa.

\section{Pendahuluan}

Pendidikan pada abad-21 ditandai dengan adanya perubahan revolusi industri 4.0 yang dikenal dengan era globalisasi. Pesatnya kemajuan teknologi dan perkembangan komunikasi diberbagai bidang termasuk dalam pendidikan. Salah satunya yang berdampak pada proses pembelajaran pada terobosan baru yang memanfaatkan jaringan dan internet. E-learning yaitu alat elektronik yang dikonstruksi sebagai sistem pada perangkat elektronik yang kemudian berkembang menjadi pembelajaran daring atau online learning.

Terkait kebijakan pemerintah di tengah pandemi covid-19, berbagai aplikasi disiapkan untuk membantu proses pembelajaran dirumah seperti google classroom, youtube, google form, zoom, rumah belajar, ruang guru, dan berbagai aplikasi lainnya. Kebijakan yang dikeluarkan oleh pemerintah dalam upaya perubahan sistem pembelajaran offline menjadi online, yang diterapkan mulai 16 Maret 2020 dengan menggunakan metode pembelajaran siswa secara daring. Berbagai inovasi dilakukan untuk membantu proses pembelajaran peserta didik. Permasalahan yang banyak dihadapi pada saat proses pembelajaran yaitu siswa seringkali merasa bosan pada saat proses pembelajaran berlangsung, untuk mengantisipasi hal tersebut guru dituntut untuk berinovasi dalam penerapan model pembelajaran dengan menggunakan media pembelajaran secara tepat, sehingga guru dapat memanfaatkan media yang sesuai dengan kebutuhan siswa. Permasalahan pembelajaran daring saat ini tidak hanya terkendala kuota, sinyal dan penguasaan IT tetapi juga kurangnya minat siswa dalam melakukan pembelajaran daring, kemampuan literasi serta dorongan siswa untuk mengikuti pembelajaran rendah. Salah satu hal yang menyebabkan pembelajaran rendah adalah minat belajar, sehingga apabila minat belajar baik kemungkinan prestasi belajar juga akan lebih baik. Untuk keberlangsungan proses pembelajaran dalam menggunakan media pembelajaran yang tepat merupakan hal yang penting diimplementasikan oleh guru dengan tujuan mendorong minat siswa dalam proses pembelajaran. Vlog diharapkan mampu sebagai solusi media pembelajaran yang mampu menarik minat siswa dalam 
situasi seperti sekarang ini. Oleh sebab itu, guru berupaya meningkatkan minat belajar siswa dengan menerapkan model pembelajaran project based learning melalui pembuatan vlog untuk materi ajar yang akan diberikan kepada siswa yang dikirim menggunakan aplikasi google classroom, dengan aplikasi google classroom siswa maupun guru dapat mengakses vlog tersebut. Dalam hal ini tidak diharuskan guru yang membuat media vlog akan tetapi media vlog juga bertujuan sebagai tugas proyek untuk siswa.

Untuk mendapatkan hasil yang maksimal dalam proses pembelajaran siswa harus mempunyai minat terhadap pelajaran sehingga siswa mampu meningkatkan prestasi belajarnya. Maka dari itu, peran guru di dalam proses pembelajaran sangat mempengaruhi minat belajar dalam diri siswa terutama dalam pembelajaran daring saat ini untuk meningkatkan minat pada diri siswa terhadap mata pelajaran tata hiding, khususnya materi pelayanan makan dan minum serta materi minuman dingin dapat mempengaruhi prestasi belajar. Pembelajaran tata hidang dengan menggunakan media vlog, diharapkan dapat memberikan kemudahan kepada siswa. Untuk melancarkan proses pembelajaran praktik tata hidang pada masa pandemi seperti sekarang ini, sehingga proses pembelajaran dapat tercapai dengan baik sesuai dengan tujuan pembelajaran.

Penelitian yang dilakukan Susanti yang berjudul "Project Based Learning: Pemanfaatan Vlog Dalam Pembelajaran Sejarah Untuk Generasi Pro Gadget" didapatkan hasil penelitian menujukkan vlog merupakan media yang dapat dimanfaatkan untuk pembelajaran berbasis Project Based Learning. Melalui tugas proyek siswa dapat memahami materi yang sedang dipelajari secara efektif. Hal tersebut dikarenakan vlog cenderung dengan kegiatan untuk bercerita yang hasilnya berupa video (audio visual). Melalui pemanfaatan vlog siswa dapat lebih kreatif dan termotivasi dalam belajar karena siswa dalam proses pembuatannya diberikan permasalahan-permasalahan untuk memicu rasa keingintahuan siswa (Susanti,2019). Adapun penelitian menurut Hendriani (2019) didapatkan hasil dengan menggunakan model pembelajaran project based learning melalui penugasan membuat vlog (video blogging) mengalami peningkatan hasil belajar siswa. Diperkuat oleh penelitian lain yang menyimpulkan bahwa Media pembelajaran vlog (video blog) merupakan salah satu solusi dalam kegiatan belajar pada era global saat ini. Hal tersebut dikarenakan generasi saat ini sudah tidak asing lagi dalam menggunakan smartphone. Dalam pelaksanaannya selama pembelajaran vlog dapat dimanfaatkan bagi siswa dalam memahami materi pembelajaran, sehingga tumbuh rasa percaya diri dalam 
belajar. Hal tersebut tentu saja akan berpengaruh terhadap hasil belajar siswa. Siswa yang memiliki rasa percaya diri yang tinggi cenderung memiliki prestasi belajar yang tinggi pula (Gita Auliya Firdaus, Robinson Situmorang, Zarina Akbar,2020). Dalam pelaksanaannya media vlog dipergunakan oleh siswa sebagai tugas proyek, sehingga siswa akan lebih kreatif dan termotivasi dalam belajar.

Dari beberapa penelitian sebelumnya sangat sedikit penelitian tentang pelaksanaan media vlog yang dilakukan khususnya di SMK pada jurusan jasa boga terutama pada mata pelajaran tata hidang, dan belum ada pemanfaatan media vlog dengan penerapan model pembelajaran Project Based Learning untuk mengetahui minat belajar dan prestasi belajar siswa. Penelitian ini dilakukan untuk mengetahui penerapan pelaksanaan media vlog yang dipergunakan oleh siswa dalam menyelesaikan tugas pembelajaran berbasis project based learning dan sekaligus mengetahui perkembangan minat dan prestasi belajar siswa dalam pembelajaran tata hidang di SMK.

\section{Metode}

Jenis penelitian ini adalah penelitian tindakan kelas (PTK) dengan teknik analisis data deskriptif kuantitatif. Tindakan yang dilakukan adalah penerapan model pembelajaran Project Based Learning melalui media vlog. Penelitian ini dilakukan dalam 2 siklus dengan tahapan-tahapan sebagai berikut: (1) Perencanaan Tindakan, (2) Tindakan, (3) Observasi, (4) Refleksi. Uraian kegiatan yang dilakukan adalah sebagai berikut:

1. Mengidentifikasi dan analisis permasalahan yang dihadapi guru dan siswa selama proses pembelajaran

2. Melakukan diskusi dengan team teaching terkait solusi pemecahan masalah pembelajaran dengan penerapan model pembelajaran Project Based Learning melalui media vlog.

Penelitian dilakukan pada siswa Kelas SMK Negeri 2 Tabanan jurusan Jasa Boga. Objek dalam penelitian ini adalah minat belajar dan prestasi belajar siswa. Teknik pengumpulan data menggunakan kuesioner, observasi, dan tes dengan instrument penelitian yaitu (1) penyebaran kuesioner minat belajar dengan indikator tabel 1. (2) tes prestasi belajar. Teknik Analisis Data

1. Mengumpulkan dan mengkaji minat belajar dan prestasi belajar siswa.

2. Mencari rata-rata presentase nilai minat belajar dan prestasi belajar siswa 
Tabel 1 Kriteria Penilaian Minat Belajar

\begin{tabular}{|c|c|c|}
\hline $\begin{array}{c}\text { Rentang Persentase } \\
\text { Nilai }\end{array}$ & Rentang Nilai & Kriteria \\
\hline $81 \%-100 \%$ & $81-100$ & Sangat Berminat \\
\hline $66 \%-80 \%$ & $66-80$ & Berminat \\
\hline $56 \%-65 \%$ & $56-65$ & Cukup Berminat \\
\hline $46 \%-55 \%$ & $46-55$ & Kurang Berminat \\
\hline$<46 \%$ & $0-45$ & Sangat Kurang Berminat \\
\hline
\end{tabular}

(Sumber: Arifin,2011)

\section{Hasil dan Pembahasan}

Dari hasil penelitian didapatkan presentase rerata nilai minat belajar siswa siklus I adalah 79,89\%. Presentase rerata minat belajar siswa pada siklus I berada pada rentang presentase nilai $66 \%-80 \%$ yang menunjukkan minat belajar siswa berada pada kategori berminat. Nilai presentase rerata ini berasal dari minat belajar siswa pada setiap indikator yaitu : 1) indikator perasaan senang sebesar 77,56\%.2) indikator keterlibatan siswa sebesar 79,78\%. 3) indikator ketertarikan sebesar 81,44\%.4) indikator perhatian siswa sebesar $80,78 \%$. Berdasarkan hasil evaluasi belajar siswa pada siklus I menunjukkan rerata prestasi belajar siswa yang mencakup tiga aspek kognitif, psikomotor dan afektif sebesar $64,86 \%$ berada pada kategori cukup. Dari hasil analisis penelitian tindakan yang telah dipaparkan diperoleh presentase prestasi belajar siswa pada siklus I sebagai berikut:

Tabel 2. Data Presentase Prestasi Belajar Siswa Siklus I

\begin{tabular}{|c|c|c|c|}
\hline No & $\begin{array}{c}\text { Kriteria Prestasi } \\
\text { Belajar Siswa }\end{array}$ & Jumlah Siswa & Presentase \\
\hline 1 & Sangat Kurang & 3 & $8,34 \%$ \\
\hline 2 & Kurang & 10 & $27,78 \%$ \\
\hline 3 & Cukup & 4 & $11,11 \%$ \\
\hline 4 & Baik & 12 & $33,33 \%$ \\
\hline 5 & Sangat Baik & 7 & $19,44 \%$ \\
\hline & TOTAL & 36 & $100,00 \%$ \\
\hline
\end{tabular}

Berdasarkan hasil penelitian prestasi belajar siklus I diatas, sebagian siswa masih belum memenuhi kriteria keberhasilan penelitian yaitu semua siswa minimal berada pada kategori baik. Pelaksanaan penelitian tindakan pada siklus I belum mencapai hasil yang maksimal karena ada beberapa permasalahan yang ditemukan dalam proses pembelajaran sehingga memerlukan perbaikan perencanaan tindakan untuk pelaksaan pembelajaran di siklus II. 
Hasil analisis data minat belajar dan prestasi belajar pada siklus II menunjukan kemajuan dari sebelumnya. Berdasarkan hasil evaluasi belajar siswa pada siklus II menunjukkan rerata minat belajar siswa sebesar 92,75\% berada pada kategori sangat berminat. Nilai presentase rerata ini berasal dari minat belajar siswa pada setiap indikator yaitu : 1) indikator perasaan senang sebesar 92,44\%. 2) indikator keterlibatan siswa sebesar 92,00\%. 3) indikator ketertarikan sebesar 94,00\%. 4) indikator perhatian siswa sebesar 92,56\%. Berdasarkan hasil evaluasi belajar siswa pada siklus I menunjukkan rerata prestasi belajar siswa yang mencakup tiga aspek kognitif, psikomotor dan afektif sebesar $82,89 \%$ berada pada kategori baik. Dari hasil analisis penelitian tindakan yang telah dipaparkan, diperoleh presentase prestasi belajar siswa pada siklus II sebagai berikut:

Tabel 3. Data Presentase Prestasi Belajar Siswa Siklus II

\begin{tabular}{|c|c|c|c|}
\hline No & $\begin{array}{c}\text { Kriteria Prestasi Belajar } \\
\text { Siswa }\end{array}$ & Jumlah Siswa & Presentase \\
\hline 1 & Sangat Kurang & 0 & $0,00 \%$ \\
\hline 2 & Kurang & 0 & $0,00 \%$ \\
\hline 3 & Cukup & 0 & $0,00 \%$ \\
\hline 4 & Baik & 16 & $44,44 \%$ \\
\hline 5 & Sangat Baik & 20 & $55,56 \%$ \\
\hline & TOTAL & 36 & $100,00 \%$ \\
\hline
\end{tabular}

Berdasarkan hasil penelitian prestasi belajar siklus II diatas, semua siswa sudah memenuhi kriteria keberhasilan penelitian yaitu semua siswa minimal berada pada kategori baik.

Tabel 4. Rekapitulasi Minat Belajar Dan Prestasi Belajar Siswa

\begin{tabular}{llcc}
\hline No & Keterangan & Siklus I & Siklus II \\
\hline A & Minat Belajar & \\
\hline 1 & Perasaan Senang & $77,56 \%$ & $92,44 \%$ \\
2 & Keterlibatan Siswa & $79,78 \%$ & $92,00 \%$ \\
3 & Ketertarikan & $81,44 \%$ & $94,00 \%$ \\
4 & Perhatian Siswa & $80,78 \%$ & $92,56 \%$ \\
\hline B & Prestasi Belajar Siswa & \\
\hline 1 & Kognitif & $63,33 \%$ & $80,91 \%$ \\
2 & Psikomotor & $66,38 \%$ & $82,36 \%$ \\
3 & Afektif & $64,93 \%$ & $91,49 \%$ \\
\hline C & Rekapitulasi Rerata Hasil Evaluasi & \\
\hline 1 & Rerata Minat Belajar & $79,89 \%$ & $92,75 \%$ \\
2 & Rerata Prestasi Belajar & $64,86 \%$ & $82,89 \%$ \\
\hline
\end{tabular}


Untuk lebih jelas perkembangan hasil analisis data minat belajar dan prestasi belajar siswa pada siklus I dan siklus II dalam presentase pada setiap indikatornya disajikan dalam gambar 1 .

Grafik 1. Rekapitulasi Setiap Indikator Minat Belajar Siswa Siklus I dan Siklus II

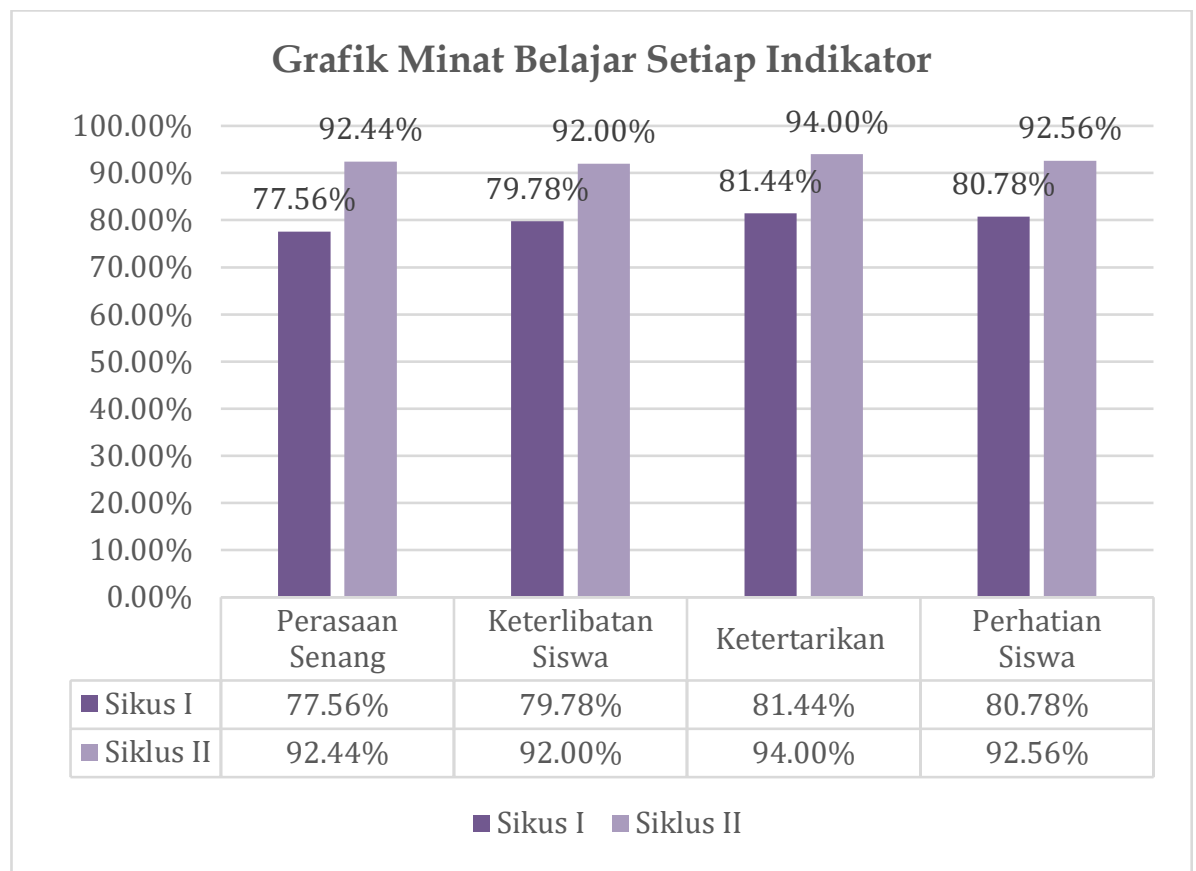

Berdasarkan presentase hasil prestasi belajar siklus I dan siklus II diatas dapat digambarkan dalam histogram pada gambar 2

Grafik 2. Rekapitulasi Setiap Indikator Prestasi Belajar Siswa Siklus I dan Siklus II

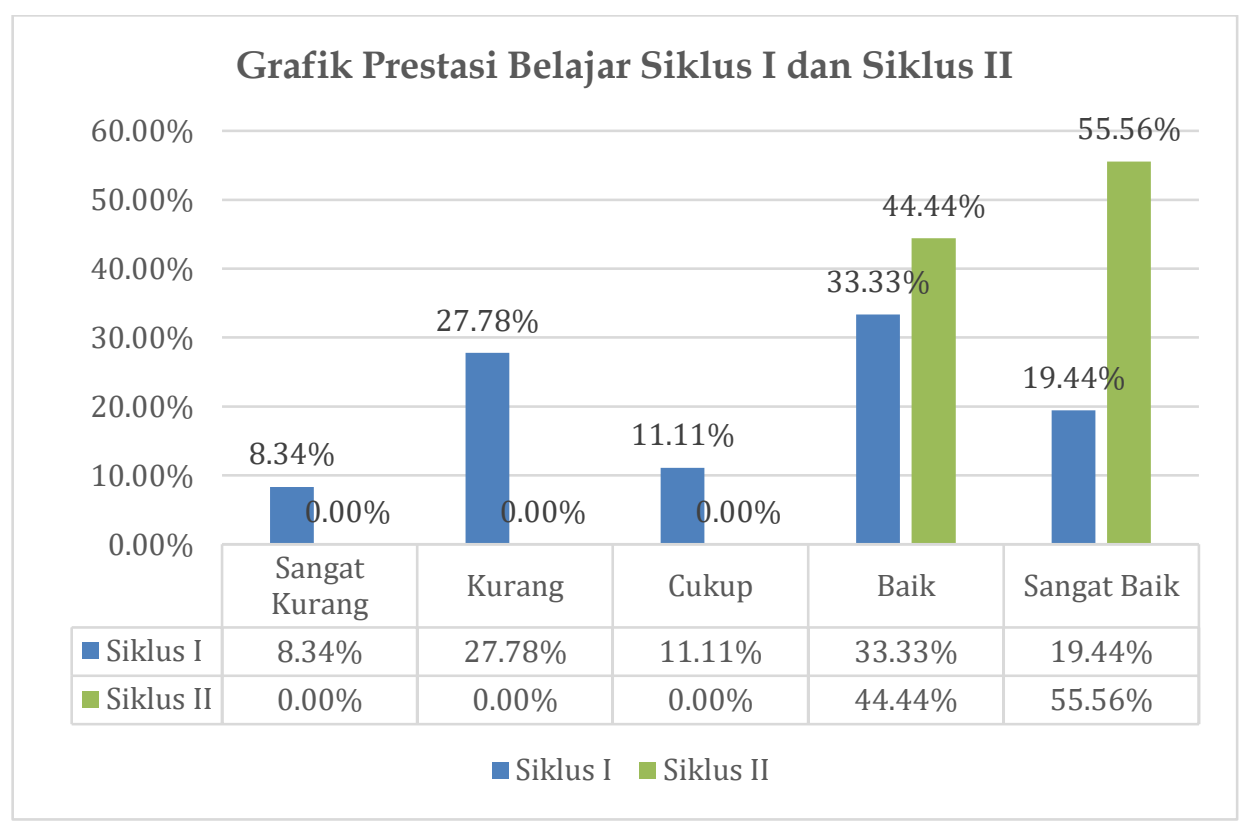


Berdasarkan deskripsi proses data hasil penelitian pada penelitian tindakan kelas ini, menunjukkan bahwa telah terjadi peningkatan pada minat belajar siswa dan prestasi belajar siswa setelah diterapkan model pembelajaran project based learning melalui media vlog. Secara umum penelitian yang telah dilakukan ini berhasil dan sudah memenuhi kriteria ketuntasan yang diharapkan.

Peningkatan hasil belajar ditunjukkan oleh peningkatan prestasi belajar yang di pengaruhi oleh minat belajar yang sangat besar peningkatannya, hal ini di dukung oleh temuan Erlando Doni Sirait (2016) yang berjudul "Pengaruh Minat Belajar Terhadap Prestasi Belajar Matematika" hasil penelitian ini adalah terdapat hubungan yang signifikan antara minat belajar terhadap prestasi belajar matematika. Siswa sangat tertarik dalam mengikuti pelajaran tata hidang, siswa sangat senang begitu diberikan praktik, hal ini di dukung oleh temuan Yustinus Setio Laksono, Gregoria Ariyanti, Fransiskus Gatot Iman Santoso (2016) yang berjudul "Hubungan Minat Belajar Siswa Terhadap Prestasi Belajar Matematika Siswa Dalam Pembelajaran Kooperatif Tipe STAD Menggunakan Komik" hasil penelitian ini adalah ada pengaruh yang signifikan antara minat belajar siswa dalam hal perasaan senang, perhatian dan kemauan secara bersama-sama terhadap prestasi belajar siswa dengan hubungan positif antara minat belajar siswa dalam hal perasaan senang, perhatian dan kemauan secara bersama-sama dengan prestasi belajar pada mata pelajaran matematika. Perhatian siswa sangat kuat saat menjelaskan tentang mata pelajaran tata hidang. Keberhasilan mata pelajaran ini sangat di dukung dengan baik dalam keterlibatan siswa secara penuh dalam pembelajaran, hal ini didukung oleh temuan Ulfatus Sa'adah, Jati Ariati (2018) yang berjudul “ Hubungan antara student engagement (Keterlibatan Siswa) dengan Prestasi Akademik Mata Pelajaran Matematika Pada Kelas XI SMA Negeri 9 Semarang, yang membuktikan bahwa proses pembelajaran telah berpusat pada siswa.

\section{Kesimpulan}

Berdasarkan hasil penelitian pada penelitian, prestasi belajar mengalami peningkatan di dukung oleh peningkatan hasil belajar siswa. Hal ini di dukung oleh keberhasilan penerapan model project based learning melalui media vlog yang berpengaruh pada peningkatan minat siswa untuk belajar yang di tunjukkan dari perasaan senang, keterlibatan siswa, ketertarikan, dan perhatian siswa. Hal ini sekaligus membuktikan bahwa penerapan model pembelajaran project based learning melalui media vlog telah berhasil meningkatkan minat belajar dan prestasi belajar siswa. 


\section{Daftar Pustaka}

Arifin, Z. (2011). Penelitian Pendidikan, Metode dan Paradigma Baru. Bandung: PT. Remaja Rosdakarya.

Arikunto, S. (2010). Prosedur Penelitian Suatu Pendekatan Praktik. Jakarta: Rineka Cipta.

Firdaus, G. A., Situmorang, R., \& Akbar, Z. (2020). Vlog Dalam Pembelajaran Ips dan Kepercayaan Diri Siswa Sekolah Dasar. Jurnal Pendidikan Dasar, 8.

Hendriani, E. (2019). Upaya Meningkatkan Hasil Belajar Dengan Project Based Learning Melalui Penugasan Membuat Vlog Materi Trigonometri. Journal On Education, 4.

Laksono, S. Y., Ariyanti, G., \& Santoso, F. G. (2021). Hubungan Minat Belajar Siswa Terhadap Prestasi Belajar Matematika Siswa Dalam Pembelajaran Kooperatif Tipe STAD Menggunakan Komik. Jurnal Edukasi Matematika dan Sains, 1.

Sa'adah, U., \& Ariati, J. (2018). Hubungan Antara Student Engagement (Keterlibatan Siswa) Dengan Prestasi Akademik Mata Pelajaran Matematika Pada Siswa Kelas XI SMA Negeri 9 Semarang. Jurnal Empati, 5-6.

Sirait, E. D. (2011). Pengaruh minat belajar terhadap prestasi belajar matematika. FORMATIF : Jurnal Ilmiah Pendidikan MIPA , 7.

Slameto. (2010). Belajar dan Faktor Faktor yang Mempengaruhinya. Jakarta: Rineka Cipta.

Susanti, E. D. (2019). Project Based Learning : Pemanfaatan Vlog Dalam Pembelajaran Sejarah Untuk Generasi Pro Gadget. . Jurnal Sejarah, Buday, dan Pengajarannya, 1.

Syah, M. (2008). Psikologi Belajar. Bandung: Remaja Rosdakarya. 